\title{
Effect of environmental capabilities on environmental strategies and performances of thermal power plants
} in Iran

\section{Leila Behnia ${ }^{1}$}

Master Student of Industrial Management

Faculty of Social Sciences

International University of Imam Khomeini, Qazvin

Iran

\section{Rohullah Bayat Ph.D.}

Associate Professor of Economic

Faculty of Social Sciences

International University of Imam Khomeini, Qazvin Iran

\section{Abstract}

The electricity industry has an important role in the economic growth and industrial dynamics in all countries. However, it is one of the main sources of environmental pollutants as well. Hence, environmental experts are always trying to reduce the amount of pollutants. This study aims to realize the relations between environmental capabilities and environmental strategies with environmental, financial and operational performances. Accordingly, questionnaires, by 39 questions, distributed among 103 participants, including environmental experts of the thermal power plants and thermal power company. Among 103 questionnaires, 70 qualified questionnaires were collected. The reliability of questioners was tested by Cronbach alpha criterion and the amount of this criterion (0.845) verified the reliability of the questionnaire. Also, the validity of the questionnaire confirmed through the Fornell and Locker methods and other factors. For testing the hypotheses of research, the method of structural equation modelling analysis was used. The empirical results show that: 1. The environmental capabilities have a positive impact on environmental strategies 2. The environmental strategies have positive impacts on financial, operational and environmental performances 3. The environmental capabilities can have positive effects on environmental, financial and operational performance through environmental strategies. These results confirm that focusing on environmental issues of thermal power plant activities, not only improve environmental performance, but also improve their operational and financial performances.

Keywords: Green supply chain, Environmental Capabilities, Environmental Strategies, Environmental Performance, Operational Performance, Financial Performance, Thermal Power Plants.

\section{Introduction}

The economic growth and development of each country depends on many factors and one of the most important of them is the development of power industry because the electricity industry is one of the important mother industries and it is an integral part of today's human's daily life. According to the IEA, the total production of electricity in non-OECD ${ }^{2}$ countries from $1977(1,796 \mathrm{TWh})$ to $2016(14075 \mathrm{TWh})$, it means that over the past 39 years the production of electricity is increased about $12039 \mathrm{TWh}$ and it is indicating an increase in global demand for Electricity energy. Also, statistics show that $67.3 \%$ of world electricity production in 2016 was generated in 
thermal power plants by fossil fuels such as coal (38.3\%), oil (3.7\%) and natural gas (23.1\%). In Iran, like many other countries, the most common method of generating electricity is using fossil fuels in thermal power plants. According to a detailed report published by Tavanir company in 2016, there are 1199 power plant units, including thermal, hydropower, atomic and renewable power plants in Iran, which 824 (69\%) of these units (equal 93 power plants), are thermal power plants and it is estimated that $81 \%$ of the electricity of Iran is supplied by these power plants. The activities of these power plants impose negative effects to the environment (Tavanir company, 2016). Combustion of fossil fuels in thermal power plants leads to emission of nitrogen oxides, sulfur dioxide and other pollutants, changing climate and also causes acid rain and so on. (Saeidi et al., 1384). Today Iran has the ninth rank of greenhouse gases emission in world and it is so worrying. According to the third Report of Energy unit in National Climate Change Department, the contribution of thermal power plants in producing greenhouse gases in 2010, 2015, 2020, 2025 and 2030 is predicted $23 \%, 23 \%, 20 \%, 21 \%$, and $22.4 \%$ respectively, as a result, the highest percentage of releasing greenhouse gases was occurred in 2010. predictions indicate that by the year 2030, a total of $15-20 \%$ of greenhouse gases emission will be associated to power plants and the majority of the pollutant will be caused by transportation industry (Tavanir company, 2016).

Due to the above mentioned problems that are caused by the activities of thermal power plants, for sustainable development of the economy without damaging the environment, it is necessary to pay more attention to environmental resources, environmental strategies, environmental performance and usage of green energies such as (solar energy, energy wind, energy inside the earth, etc.). this study focuses on green supply chain management of thermal power plants by emphasizing on environmental capabilities and environmental strategies and effect of this two factor on power plant performances. environmental capability refers to the ability of an organization to carry out organizational activities in compatible with environmental goals (Grant, 1991), and the Environmental Strategy also refers to the strategies that used to reduce the negative impacts of variety activities of companies on Environment (Rostamzadeh and Siaban, 2016).

Also it should be mentioned that the evaluated performances of this study are containing environmental, financial and operational performances. In next parts, the fully concept of each performance and their indicators are described.

Generally, this research wants to response this question that what is the impact of environmental capabilities on performances of thermal power plants through environmental strategies in Iran? According to the above question this research has three objectives: 1. Investigating the Impact of Environmental Capabilities on Environmental Strategies 2. Investigating the Impact of Environmental Strategy on Environmental, Financial and Operational Performance 3. Identifying the Indirect relationship between Environmental Capabilities on Financial, Environmental and Operational Performance.

This paper includes 5 sections. This section introduces the general subject, importance of this subject, the main question and aims of the research and the road map of this paper. In section 2, the paper will review the literature of past researches about the variables of this research including green supply chain management, environmental capabilities, environmental strategies and environmental, financial and operational performance. In section 3, the paper will represent the research model and hypostases and explain about research methodology. In section 4 paper will describe about responders features, reliability and validity of questioner and fitness of general model and the result of testing hypostases. Section 5 will review the whole article and describe the conclude of it.

\section{Literature review}

Today, supply chain management is an important factor in the success of many industries but also we have a new concept of supply chain management called Green Supply Chain Management. Green Supply Chain Management is a concept that has been formed in recent years to ensure the provision of environmental priorities at all stages of production, transportation, and consumption of a good and it's welcomed by environmental authorities, consumers, governments and organizations. The main purpose of green supply chain management is improving processes of production, packaging, storage, and transportation of products to minimize the damage caused by supply chain activities and increase the health of the community (Khosravani, 2015). 


\section{(C) Center for Promoting Education and Research}

WWW.cpernet.org

Green supply chain management integrates environmental thinking into supply chain management and covers all production activities until product recycling and requires a high level of research and planning (Gao et al., 2018). Also, this concept can be defined as a strategic approach that evaluates supply chain activities with a measure of their compatibility with the environment (Shah Bandarzadeh and Kebgani, 2017). Organizations can reduce their negative environmental impacts through green supply chain management, and achieve optimum use of resources and energy (Nik Nejad, 2011). One of the most important concepts of a green supply chain is environmental capabilities of the supply chain.

Grant (1991) defines organizational capabilities as the organization's ability to carry out the activities. As a result, the environmental capability of an organization is the ability of an organization to carry out organizational activities in an environmentally sustainable manner. Grant believes that the internal resources of organizations are the competitive advantage of an organization and are considered as an important factor in organizational capabilities.

Judge and Douglas (1998) argue that organizational resources have a positive effect on the integration of organizational capabilities with environmental issues and strategic policies and this integrity will be improved organizational performances. Therefore, organizations can benefit from the use of environmental capabilities to increase the internal capabilities of the organization, such as environment-friendly technologies (Dean and Brown, 1995).

If the organization's environmental capabilities are effective in managing a green supply chain, it will be preserved as a valuable asset and provided a competitive advantage for the organization. (Bae, 2017). Organizations can create internal capabilities by means of environmental capabilities through green supply chain management, and also they can gain competitive advantage through the environmentally cooperation with the members of the supply chain, thus, the environmental capability can improve the organization's performance. In addition, the environmental capabilities of green supply chain cause sustainable development and provide barriers for competitors for entry to the market. Therefore, companies benefit from a monopoly position in the market through green supply chain management (Hart,1995).

After whole explanations that were done about environmental capabilities, it should be mentioned that these environmental capabilities are not only enough for improving the organization's performances. There should be used some strategies to apply these capabilities. For example, having an environment expert employee in the organization is an environment capability but it does not guarantee the environmentally performance of an organization so we need some internal and external environmental strategies for using the environment capabilities of the organization. The term "Environmental Strategies", refers to all the strategies used to reduce negative environmental impacts inside and outside of the organization. An active environmental strategy requires routine and operational changes and is defined as one of the organizational competencies (Rostam Zadeh and Siaban, 2016).

In general, supply chain strategies are divided into two general categories: response strategies (equivalent to the Porter Cost Reduction Strategy) and efficiency strategies (equivalent to the Porter Differentiation Strategy). In green supply chain management, a combination of these strategies is used, by name of "environmental strategies". Deploying environmental strategies cause saving energy resources, reducing pollution by using environmentfriendly raw materials, reducing waste. In addition, they will reduce the costs of environmental degradation by innovating production processes (Imani \& Ahmadi, 2009).

For implementing environmental strategies, organizations should employ authorities who have enough experts in this regard, and the next step is the continuing emphasis of senior managers on environmental managing to downstream managers. By doing this, environmental management culture is created at the organization level (Brown and Dray, 1996).

One of the most important purposes of applying environmental strategies is improving organizational performances. this study considers these 3 performances and also wants to proper the effect of environmental strategies on these performances. 
One of these performances is Environmental Performance. According to the ISO $^{3}$ 14031, Environmental Performance means managing results on the environmental aspects of an organization. In other words, environmental performance is the implementation of environmental-friendly activities that can be measured by international and national criteria (Sarumpaet, 2005).

There are many indicators for measuring the environmental performance of industries. The newest developed environmental standard, ISO 14031, has provided specific indicators in this issue. The International Standard ISO 14031 is a management process that enables the organization to assess its environmental performance by using key indicators and provides reliable information for stakeholders.

The indicators that are used in this research, are divided in two general categories: 1. Executive function indicators such as water consumption, pollution rate, amount of contamination and waste, environmental hazards and etc.2. management performance Indicators such as level of achieving environmental, the number of environmental authorities, number of the equipment for recycling and etc. (Tavanir Specialist Company, 2016).

According to the industry surveyed by this research, the electric industry, environmental performance for this industry can be described as follow:

a method of producing electricity that not only considers geographical and climatic conditions, Economic and ... but also pay attention to environmental issues (Tavanir Specialist Company, 2016). Financial performance is the second performance of this study that is described as follow:

One of the most important reasons for measuring organizational functions is to control and manage the performances. Without measuring the organization's performance, it cannot be controlled, and whatever that cannot be controlled cannot be managed, therefore, evaluating organizations are critical. One of the most important performances of an organization is the financial performance, and consequently, the evaluation of financial performance is very important. financial indicators that can be used to evaluate this performance include: improving financial structures, improving incomes, reducing production costs, collecting receipts, optimizing Assets management (Rojoei and et al., 2017).

Another important performance is Operational performance. Operational Performance is the ability of the manufacturing industry to produce and send products to customers as efficiently as possible. the indicators that are used to measure this performance in this research, including increasing the number of goods delivered at the time, reducing the amount of waste, increasing the production line, Improve capacity utilization (Zhu \& et al, 2008a).

The most important reason of analysing the effect of environmental capabilities and strategies on the operational and financial performances along with environmental performance is that the researcher wants to answer this question, do the environmentally activities are in contrast with other aims and activities of power plants? this question will be answered in the next parts.

\section{The Research Model and Methodology}

\subsection{Research model}

The main purpose of this study is recognizing the relationship of environmental capabilities and strategies with environmental, financial and operational performances. For analyzing this relationship, a conceptual model is needed. The conceptual model of this research is made from the combination of past researches conceptual models.

The relationship between environmental capabilities and environmental strategies and also the relationship between environmental strategies and environmental performance in the conceptual model of this research is adopted from the conceptual model of Bae (2016).

In addition, the relationship between environmental strategies with operational performance is adapted from the conceptual model of Golicic and Smith (2013). 
also, the relationship between environmental strategies and financial performance is adapted from the conceptual model of Siban and Rostamzadeh (2016). (figure1) shows the conceptual model of this research.

\section{Figur1 Conceptual model}

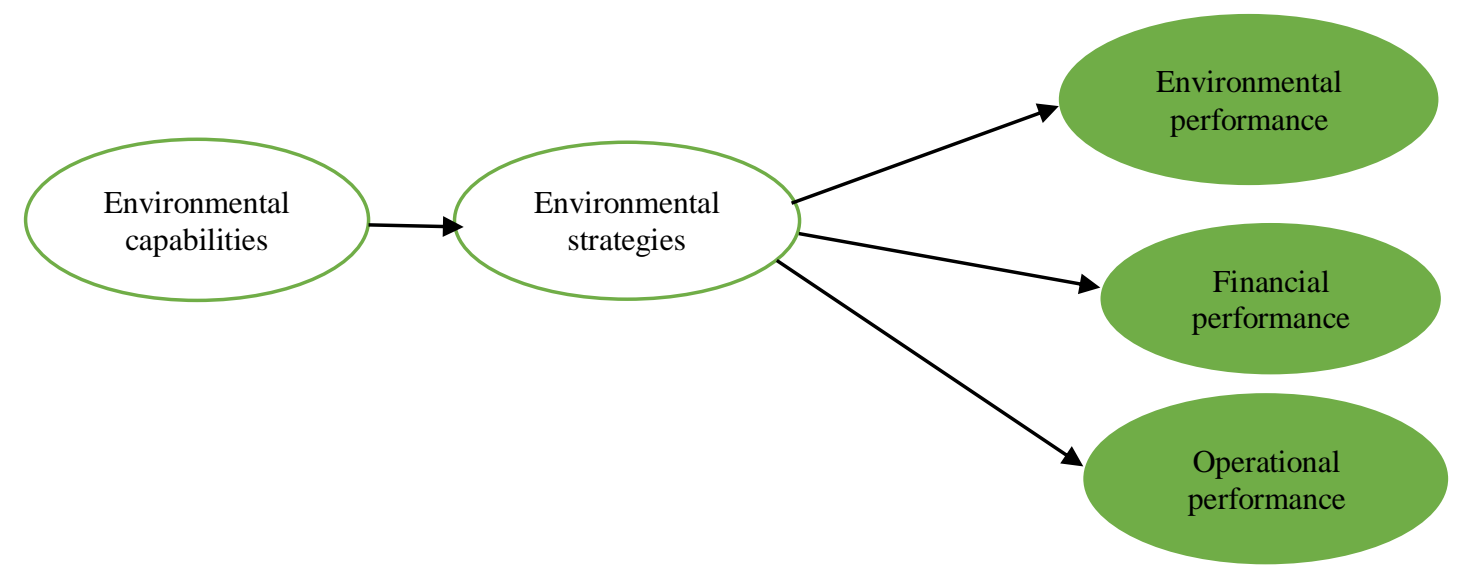

Adapted from (Rostamzadeh and Siaban, 2016), (Golicic and Smith, 2013), (Sung BAE, 2017)

\subsection{Research Hypotheses}

The relationship between the variables is already explained in the literature review section and the conceptual model and hypotheses of this research are created based on them.

The hypotheses of this study are divided into two groups. The first group considers hypotheses that measure the indirect impact of organizational capabilities on the performances (financial, environmental, and operational) of thermal power plants. The second group consider the hypothesis that measures the impact of environmental capabilities on environmental strategies model and also hypotheses that measure the direct impact of the organization's environmental strategies on financial, environmental and operational functions.

All the relationship between variables is described by the authoritative source in the research model section. Hypotheses are as follows:

1.The environmental capabilities of Iran's thermal power plants will positively affect the environmental performance of their green supply chain.

2. The environmental capabilities of Iran's thermal power plants will positively affect financial performance through environmental strategy.

3.The environmental capabilities of Iran's thermal power plants will positively affect operational performance through environmental strategy.

Subsequently, the sub-hypotheses of the research are presented, which includes:

4.The environmental capabilities of Iran's thermal power plants have a positive impact on the environmental strategy of their green supply chain.

5.Environmental strategies of the green supply chain of Iran's thermal power plants have a positive impact on environmental performance.

6.Environmental strategies of the green supply chain of Iran's thermal power plants have a positive impact on financial performance.

7 Environmental strategies of the green supply chain of Iran's thermal power plants have a positive impact on operational performance.

\subsection{Research Methodology}

The objective of this research is to analyze the relationships between environmental capabilities and environmental strategy with the environmental, financial and operational performance. To achieve the objective, this 
research uses the conceptual and operational definitions come from prior research. All the variables of research are measured as perceptions on a five Likert scale. The measuring items are shown in (Table 1).

\section{Table1 The measuring items of the variables}

\begin{tabular}{|c|c|}
\hline Structures & Sub-structures \\
\hline \multirow{4}{*}{$\begin{array}{l}\text { Environmenta } \\
\text { l Capability }\end{array}$} & EC1) Physical resources such as environmental protection equipment \\
\hline & EN2) Specialist human Resource in content of environmental activities \\
\hline & EC3) Organizational resources (suitable facilities) \\
\hline & EC4) Quality control systems \\
\hline \multirow{4}{*}{$\begin{array}{l}\text { Grant } \\
(1991)\end{array}$} & $\begin{array}{l}\text { EC5) Technological resources (unique technology for producing high quality } \\
\text { products) }\end{array}$ \\
\hline & EC6) Partners with rich backgrounds \\
\hline & EC7) Environmental subsidies \\
\hline & EC8) Financial support of environmental activities \\
\hline \multirow{4}{*}{$\begin{array}{l}\text { Environmenta } \\
\text { I Strategy }\end{array}$} & ES1) Contemplation with partners for environmental management \\
\hline & ES2) Share environmental management issues with employees \\
\hline & ES3) Trying to minimize contamination \\
\hline & ES4) Agreement on Environmental Objectives with Suppliers \\
\hline \multirow{8}{*}{$\begin{array}{l}\text { Dyer \& Singh } \\
\quad(1998)\end{array}$} & ES5) Create mutual understanding of environmental responsibility with suppliers \\
\hline & $\begin{array}{l}\text { ES6) Collaboration with suppliers to reduce the negative environmental impacts of } \\
\text { activities }\end{array}$ \\
\hline & ES7) Joint planning with suppliers to anticipate and solve environmental problems \\
\hline & $\begin{array}{l}\text { ES8) Joint decision making with suppliers on methods of reducing the overall } \\
\text { negative environmental impact of products or services }\end{array}$ \\
\hline & ES9) Close communication with consumers to solve environmental problems \\
\hline & ES10) Sharing environmental information with consumers \\
\hline & ES11) Flexible communication with consumers about environmental issues \\
\hline & ES12) Reflecting consumers environmental needs in goods or services \\
\hline \multirow{6}{*}{$\begin{array}{c}\text { Environmenta } \\
\text { l Performance } \\
\text { Zhu et al } \\
\text { (2008) }\end{array}$} & EP1) Amount of air pollution (COx, SOx, NOx emissions) \\
\hline & EP2) Amount of sewage production \\
\hline & EP3) Number of environmental hazards \\
\hline & EP4) The amount of toxic / harmful / hazardous substances used \\
\hline & EP5) Solid waste production \\
\hline & EP6) Improvement of the environmental situation \\
\hline \multirow{3}{*}{$\begin{array}{l}\text { Financial } \\
\text { Performance }\end{array}$} & FP1) Improving financial structures \\
\hline & FP2) Income opportunities \\
\hline & FP3) receivables collection \\
\hline \multirow{3}{*}{$\begin{array}{c}\text { Rojoei and et } \\
\text { al. } \\
(2017)\end{array}$} & FP4) Optimal Capital Management \\
\hline & FP5) Asset use \\
\hline & FP6) Production costs \\
\hline \multirow{6}{*}{$\begin{array}{c}\text { Operational } \\
\text { Performance } \\
\text { Zhu et al } \\
(\mathbf{2 0 0 8 )}\end{array}$} & OP1) Increasing the amount of goods delivered in time \\
\hline & OP2) Reduce the amount of waste \\
\hline & OP3) Improving capacity utilization \\
\hline & OP4) Upgrade product quality \\
\hline & OP5) Increase production line \\
\hline & OP6) Reduce inventory levels \\
\hline
\end{tabular}

The population of the research is including environmental authorities of the thermal power company and environmental authorities of whole thermal power plants of Iran. responding persons are selected by random sampling among the population of research that the number of them was 103 persons. These persons are performing environmental management in thermal power plants and that is why they are proper to answer the questionnaires. the questionnaires were sent to respondents by email. The period of collecting data was between July 2018 and August 2018, and among 81 questionnaires that were distributed, only 30 questionnaires were answered and researcher was forced to send questionnaires to all the 103 persons to collect more data and finally, 70 of them were filled and were used for analyzing. To achieve the objective, this research used various analytical methods. 
First, the Structural Equation method. It is made for investigating the causal relationships between independent variables and dependent variables, and the results can be suggested based on the results of the path analysis (path factor), and bootstrapping test (T-value).

Second, Explanation factor (R2) is used for analyzing the impact of the independent variable on dependent variables and analyzing the fitness of the structural model. The amounts of $0.19,0.33$ and 0.67 respectively show the week, a normal, strong relationship of two variables (Nasr Abadi, 2014) and as the amount of R2 increases, the fitness of structural model increases.

Third, the reliability of the questionnaire's variables is measured by Cronbach's alpha coefficients. If the amount of coefficient be higher than 0.7 the questionnaire has reliability (Qazi Tabatabae \& afrashte, 2011)

Forth, discriminant validity is tested by comparison average variance extracted (AVE) with a square of a correlation coefficient. If AVE is higher than the square, discriminant validity is good. the Convergent Validity is tested by two indicators of AVE and CR. If AVE>0.5 (fornell \& larker, 1981) and CR >0.7 (Alarcón \& Sánchez, 2015) and CR> AVE, the Convergent Validity is good.

Fifth, Confirmatory factor (load factor) analysis method has been used to examine the correlation between indices and their variables. If the amount of load factor $>0.6$ it can claim that the indicator has a good correlation with the variable and the amounts of under 0.4 show week relationship of indicator and variable.

Sixth, SRMR index is used for measuring the general fitness of the model. If the amount of this index is lower than 0.05, shows good fitness (Joreskog \& Sorbom, 1981).

All the measurements were done by Smart-PLS software. The results are shown in (Table2).

Table2 Validity and Reliability

\begin{tabular}{|c|c|c|c|c|c|c|c|}
\hline \multirow[b]{2}{*}{ Variable } & \multirow[b]{2}{*}{ Indicators } & \multicolumn{3}{|c|}{ Validity } & \multicolumn{3}{|c|}{ Reliability } \\
\hline & & $\begin{array}{l}\text { Load } \\
\text { Factor }\end{array}$ & AVE & CR & $\mathrm{R}^{2}$ & $\begin{array}{c}\text { Cronbach's } \\
\text { alpha }\end{array}$ & $\begin{array}{r}\text { Fitness } \\
\text { of model }\end{array}$ \\
\hline \multirow{6}{*}{$\begin{array}{l}\text { Environmen } \\
\text { tal Capability }\end{array}$} & EC1 & 0.849 & \multirow{6}{*}{0.638} & \multirow{6}{*}{0.913} & & \multirow{6}{*}{0.889} & \multirow{19}{*}{$\begin{array}{l}\text { SRMR= } \\
0.043\end{array}$} \\
\hline & EC2 & 0.796 & & & & & \\
\hline & EC3 & 0.846 & & & - & & \\
\hline & EC4 & 0.801 & & & & & \\
\hline & EC5 & 0.805 & & & & & \\
\hline & EC6 & 0.687 & & & & & \\
\hline \multirow{13}{*}{$\begin{array}{l}\text { Environmen } \\
\text { tal Strategy }\end{array}$} & ES1 & 0.833 & \multirow{13}{*}{0.609} & \multirow{13}{*}{0.949} & \multirow{13}{*}{0.621} & \multirow{13}{*}{0.941} & \\
\hline & ES2 & 0.829 & & & & & \\
\hline & ES3 & 0.649 & & & & & \\
\hline & ES4 & 0.729 & & & & & \\
\hline & ES5 & 0.752 & & & & & \\
\hline & ES6 & 0.829 & & & & & \\
\hline & ES7 & 0.819 & & & & & \\
\hline & ES8 & 0.874 & & & & & \\
\hline & ES9 & 0.792 & & & & & \\
\hline & ES10 & 0.727 & & & & & \\
\hline & ES11 & 0.764 & & & & & \\
\hline & ES12 & 0.745 & & & & & \\
\hline & EP1 & 0.578 & & & & & \\
\hline
\end{tabular}


(C) Center for Promoting Education and Research

\begin{tabular}{|c|c|c|c|c|c|c|}
\hline \multirow{3}{*}{$\begin{array}{c}\text { Environmen } \\
\text { tal } \\
\text { performance } \\
\end{array}$} & EP2 & 0.916 & \multirow[t]{3}{*}{0.616} & \multirow[t]{3}{*}{0.862} & \multirow[t]{3}{*}{0.567} & \multirow[t]{3}{*}{0.787} \\
\hline & EP3 & 0.752 & & & & \\
\hline & EP4 & 0.852 & & & & \\
\hline \multirow{5}{*}{$\begin{array}{l}\text { Financial } \\
\text { Performance }\end{array}$} & FP1 & 0.953 & \multirow{5}{*}{0.731} & \multirow{5}{*}{0.931} & \multirow{5}{*}{0.492} & \multirow{5}{*}{0.924} \\
\hline & FP2 & 0.791 & & & & \\
\hline & FP3 & 0.881 & & & & \\
\hline & FP4 & 0.799 & & & & \\
\hline & FP5 & 0.839 & & & & \\
\hline \multirow{6}{*}{$\begin{array}{l}\text { Operational } \\
\text { Performance }\end{array}$} & OP1 & 0.897 & \multirow{6}{*}{0.765} & \multirow{6}{*}{0.942} & \multirow{6}{*}{0.387} & \multirow{6}{*}{0.907} \\
\hline & OP2 & 0.897 & & & & \\
\hline & OP3 & 0.879 & & & & \\
\hline & OP4 & 0.897 & & & & \\
\hline & OP5 & 0.799 & & & & \\
\hline & OP6 & -0.397 & & & & \\
\hline
\end{tabular}

WWW.cpernet.org

It should be described that during the statistical calculations some of the indicators were recognized inadequate and they were eliminated. These indicators are considering: EC7, EC8, EP5, EP6, and FP6. The analyze was done by the remain indicators and results are as follow:

Based on load factor column of table3, it can be understood that the values of load factor for all items except OP3, are greater than 0.4 and they can be used for measuring their own variables, so OP3 is deleted because it cannot do it. Also, the negative sign of this index indicates a reversal influence of this indicator on the desired variable.

According to AVE and CR columns, amounts of Average Variance Extracted (AVE) for all variables is greater than 0.5 and the composite reliability (CR) value for all of them is more than 0.7 and in all cases, the composite reliability value is greater than the average value of the variance extracted so the convergent validity is good.

According to the amounts of R2 column, $62.1 \%$ changes of environmental strategies, $56.7 \%$ changes of environmental performance, $49.2 \%$ changes of financial performance and $38.7 \%$ changes of operational performance is depending to the independent variable of environmental capability. Considering the high values of the coefficient of determination that is obtained for each of the dependent variables, it is concluded that the structural model has an acceptable fitness.

Based on the result of estimating the SRMR index for the research model that is equal to 0.043 , it can be understood that the suggested model of research is well suited.

According to the above table, the amount of Cronbach's alpha value is equal to 0.847 , which is indicating the reliability of the questionnaire.

Also, the results of testing divergent validity are shown in (table 3).

Table 3 The square correlation between variables and the AVE index on the main diameter for each factor

\begin{tabular}{|c|c|c|c|c|c|}
\hline Variable & $\begin{array}{c}\text { Environme } \\
\text { ntal Capability }\end{array}$ & $\begin{array}{l}\text { Environmental } \\
\text { Performance }\end{array}$ & $\begin{array}{r}\text { Environme } \\
\text { ntal Strategies }\end{array}$ & $\begin{array}{r}\text { Financial } \\
\text { Performance }\end{array}$ & $\begin{array}{c}\text { Operational } \\
\text { Performance }\end{array}$ \\
\hline $\begin{array}{c}\text { Environmental } \\
\text { Capability }\end{array}$ & 0.799 & & & & \\
\hline $\begin{array}{l}\text { Environmental } \\
\text { Performance }\end{array}$ & 0.668 & 0.785 & & & \\
\hline $\begin{array}{c}\text { Environmental } \\
\text { Strategies }\end{array}$ & 0.780 & 0.753 & 0.781 & & \\
\hline
\end{tabular}


(C) Center for Promoting Education and Research

$\begin{array}{cccccc}\begin{array}{c}\text { Financial } \\ \text { Performance }\end{array} & 0.356 & 0.463 & 0.702 & 0.855 & \\ \begin{array}{c}\text { Operational } \\ \text { Performance }\end{array} & 0.234 & 0.518 & 0.622 & 0.672 & 0.875 \\ & & & & & \end{array}$

According to the above table, the AVE index (elemental diameter) for all factors is larger than the correlation between the two factors, so all factors have divergent validity.

\section{The Results of an Empirical Test}

\subsection{General characteristics of responders}

There are some general characteristics of the responders on the basis of the collected data as follows.

Table 4 Descriptive statistics of respondents

\begin{tabular}{|c|c|c|c|}
\hline Variable & & Quantity & Percent \\
\hline \multirow[t]{2}{*}{ Sexual } & Women & 21 & 30 \\
\hline & Man & 49 & 70 \\
\hline \multirow{3}{*}{ Education } & Bachelor & 31 & 44.5 \\
\hline & MA & 36 & 51.5 \\
\hline & P.H.D & 3 & 4 \\
\hline \multirow{3}{*}{ Age } & $<25-35<$ & 21 & 30 \\
\hline & $<35-45<$ & 31 & 46 \\
\hline & $45<$ & 18 & 24 \\
\hline \multirow{3}{*}{ Work experience } & $10>$ & 17 & 24 \\
\hline & $<10-20<$ & 38 & 55 \\
\hline & $20<$ & 15 & 21 \\
\hline
\end{tabular}

According to the presented information in the above table, most respondents are men (70\%). The majority of the respondents had an MA degree (36\%) and the majority of them are between 35 and 45 years old $(31 \%)$ and their work experience are often between 10 and 20 years (38\%).

\subsection{Results of Empirical tests}

The results of analyzing hypostases are as follow:

Table5 results of hypotheses test

\begin{tabular}{cccccc}
\hline $\begin{array}{c}\text { Number of } \\
\text { hypotheses }\end{array}$ & Hypotheses & $\begin{array}{c}\text { Type of } \\
\text { impact }\end{array}$ & Path Factor & T- value & Result \\
\hline 1 & EC-ES-EO & Indirect & 0.587 & 10.334 & Accept \\
\hline 2 & EC-ES-FP & Indirect & 0.574 & 15.473 & Accept \\
\hline 3 & EC-ES-OP & Indirect & 0.485 & 9.464 & Accept \\
\hline 4 & EC--- ES & Direct & 0.780 & 20.252 & Accept \\
\hline 5 & ES--- EO & Direct & 0.753 & 14.609 & Accept \\
\hline 6 & ES--- FP & Direct & 0.702 & 21.382 & Accept \\
\hline 7 & ES--- OP & Direct & 0.622 & 10.105 & Accept \\
\hline
\end{tabular}

According to the results of the above table:

1.The environmental capabilities have a positive effect on environmental performance through environmental strategy (H1 supported). The value of the path coefficient is 0.587 and the value of $\mathrm{t}$-statistic is 10.334 . according to the amount of path coefficient that is between 0.3 and 0.6, the relationship of these two variables is moderate and 
directional, and in the other hand, the amount of T-value is greater than 1.96, so the relationship of these two variables is meaningful and therefore the hypothesis is accepted.

2.The environmental capabilities have a positive effect on financial performance through environmental strategy ( $\mathrm{H} 2$ supported). the value of path coefficient is 0.574 and the value of t-statistic is 15.437 . according to the path coefficient that is between 0.3 and 0.6 , the relationship of these two variables is moderate and directional, and on the other hand, the amount of T-value is greater than 1.96, so the relationship of these two variables is meaningful and therefore the hypothesis is accepted.

3.The environmental capabilities have a positive effect on operational performance through environmental strategy (H3 supported). the value of the path is 0.485 and the value of $t$-statistic is 9.464 . according to the path coefficient that is between 0.3 and 0.6 , the relationship of these two variables is moderate and directional, and on the other hand, the amount of T-value is greater than 1.96, so the relationship of these two variables is meaningful and therefore the hypothesis is accepted.

4. The environmental capabilities have a positive impact on the environmental strategy (H4 supported). the value of path coefficient is 0.780 and the value of $t$-statistic is 20.252. according to the path coefficient value that is greater than 0.6, The relationship between these two variables is strong and directional, and on the other hand, the amount of T-value is greater than 1.96, so the relationship of these two variables is meaningful and therefore the hypothesis is accepted.

5.Environmental strategies have a positive impact on environmental performance (H5 supported). The value of the path coefficient is 0.753 and the value of t-statistic is 14.609 . according to the path coefficient value that is greater than 0.6, The relationship between these two variables is strong and directional, and on the other hand, the amount of T-value is greater than 1.96, so the relationship of these two variables is meaningful and therefore the hypothesis is accepted.

6.Environmental strategies of the green supply chain have a positive impact on financial performance (H6 supported). The value of the path coefficient is 0.702 and the value of t-statistic is 21.382 . according to the path coefficient value that is greater than 0.6, The relationship between these two variables is strong and directional, and on the other hand, the amount of T-value is greater than 1.96, so the relationship of these two variables is meaningful and therefore the hypothesis is accepted.

7.The environmental strategies of the green supply chain have a positive impact on operational performance ( $\mathrm{H} 7$ supported). the value of path coefficient is 0.622 and the value of the t-statistic is 10.105 . according to the path coefficient value that is greater than 0.6, The relationship between these two variables is strong and directional, and on the other hand, the amount of T-value is greater than 1.96, so the relationship of these two variables is meaningful and therefore the hypothesis is accepted. The structural model of SEM ${ }^{4}$ is shown in (Figur2).

\section{Figur2 Final conceptual model}

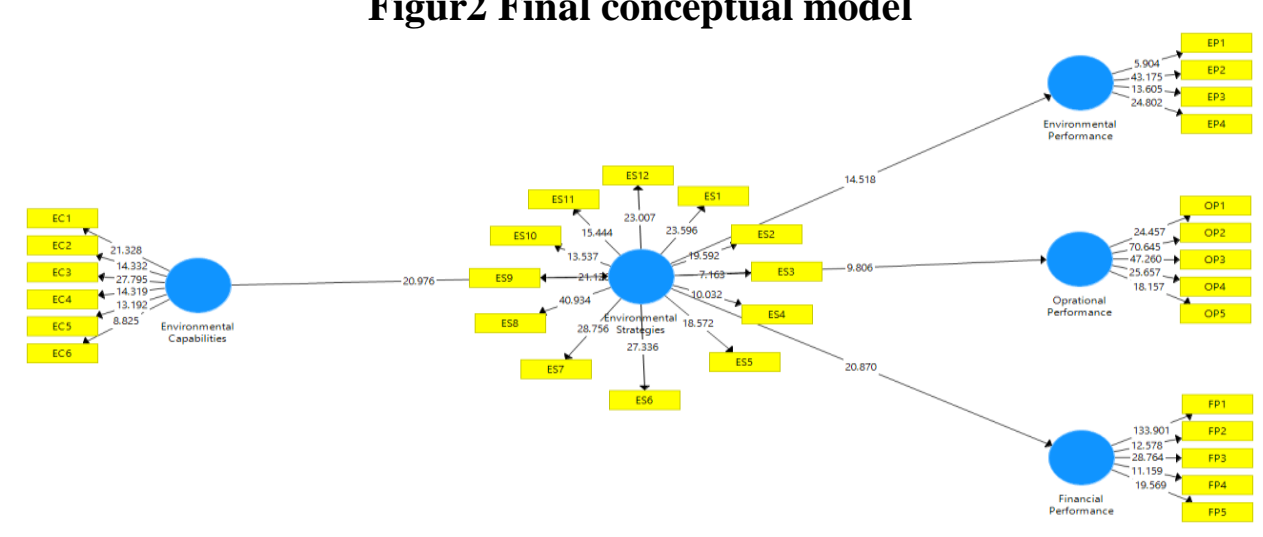

${ }^{4}$ Structural Equation Model 


\section{(c) Center for Promoting Education and Research}

WWW.cpernet.org

The results of the hypotheses test have shown that all hypotheses of the research were correct and all of them were accepted. the final model of research is shown in the above figure. This model is designed based on the results of hypotheses test.

\subsection{Discussion}

The results of the above analyses are interpreted as follows:

$\checkmark$ Environmental capabilities have a positive impact on the environmental strategies of thermal power plants. The correctness of this issue has been proven in the fourth hypothesis of this study, while the correctness of this issue has been proven in earlier studies (Chan, 2005). Therefore, that part of the model, which shows the relationship between environmental capabilities and environmental strategies, is backed up by the proof of this hypothesis.

$\checkmark$ Environmental strategies have a positive impact on the environmental performance of thermal power plants. The correctness of this issue has been proven in the fifth hypothesis of this study, in addition, the result of testing this hypothesis is compatible with the previous researches (Bae, 2016; Giovanni, 2012; Shukla et al, 2009). So that part of the model, which shows the link between environmental strategies and environmental performance, is backed up by the proof of this hypothesis.

$\checkmark$ Environmental strategies have a positive impact on the financial performance of thermal power plants. The correctness of this issue has been proven in the sixth hypothesis of this research, in addition, the result of testing this hypothesis is compatible with the previous researches (Rostamzadeh and Siaban, 2016). So that part of the model, which shows the relationship between environmental strategies and financial performance, is backed up by the proof of this hypothesis.

$\checkmark$ Environmental strategies have a positive impact on the operational performance of power plants. The correctness of this issue has been proven in the seventh hypothesis of this study, in addition, the result of testing this hypothesis is compatible with the previous researches (Golicic and Smith, 2013). So that part of the conceptual model, which shows the relationship between environmental strategies and operational performance, is backed up by the proof of this hypothesis.

$\checkmark$ Environmental capabilities of thermal power plants have a positive impact on environmental, financial and operational performance through environmental strategies. The correctness of this problem has been proved in the first to third hypotheses of this research. The existence of a positive relationship between environmental capabilities and environmental performance through environmental strategies has been proven in previous researches (Bae, 2016), but there are no previous reports about two other performances.

\section{Conclusion}

The objective of this research is to verify the relationships between environmental capabilities and environmental strategy with environmental, financial and operational performance. To achieve the objective, this research ascertains the relationships between the variables and extracts the definitions of the variables through prior research. The questionnaires were sent to environmental authorities of thermal power plants, and 70 data were used in the analysis. The theoretical implications of the results are suggested in the above discussion and managerial implications, limitations, and future research directions are as follows. The managerial implications of the results are as follows.

First, environmental experts in thermal power plants should recognize the importance of asset-based resources as well as knowledge-based resources for providing environmental capabilities. Thermal power plants with more resources can better apply environmental strategies. Therefore, managers of thermal power plant need human resources who can learn and perform the best environmental managing methods for gaining the competitive advantages of adverting environmental issues.

Second, managers of thermal power plants should consider their suppliers when developing an environmental strategy. One of the most important issues for environmental managing of thermal power plants is the 
environmental performance of their suppliers. It can claim that one of the most important suppliers of thermal power plants is petrochemical industry because this industry supplies the fuels of thermal power plants and if they produce non-standard fuels and give these fuels to power plants, the air pollution will be occurring during the process of producing electricity. absolutely the environmental strategies of this industry in cooperative with thermal power plants can impact the environmental performance of both industries. So it is suggested to the managers of thermal power plants to corporate with all of their suppliers especially petrochemical industry to find the best ways for improving their environmental performances and reduce the damages that are caused by their activities.

In another hand, thermal power plants should be in close contact with consumers to solve environmental problems. It is clear that if the demand for electricity below, less electricity is needed, and as a result, the negative environmental effects of power plant activities will be reduced. therefore, the electricity industries in Iran should inform their consumers about the amount of the fuels that is used for supplying the electricity consumption of consumers in one month's and the result of burning this amount of fuels in polluting air and other negative consequences that accrues for producing the assumed amount of one month's electricity consumption. also, they can explain to people that saving this amount of burned fuels how can benefit the people and the country. one of the most effective instrument for informing people nowadays is TV programs, social networks, and other media. so electricity industries in partnership with their suppliers can use those instruments for informing people and try to save National capital and improve their environmental performances.

As a result, managers of thermal power plants need to consider their consumers and suppliers in order to have a high level of environmental performance when designing an environmental strategy.

Despite the implications, there are limitations to this research. First, safety sensitivities of power plants and problems of entering the researcher into the environment of thermal power plants for presenting the environmental experts of power plants.

Second, avoiding some responders for answering the questionnaires and delay of the individuals to submit questionnaire responses.

It is suggested to the future researchers:

1.Recognizing The direct impact of environmental capabilities on environmental, financial and operational performance.

2.Studying the impact of environmental capabilities and environmental strategies on the other activities of Iran's thermal power plants.

\section{Resources}

Azar., Adel. Mahmoudian., Omid. Hashemi., Mehdi., 2016. Presenting a method for assessing the performance of the green supply chain of Asalouyeh petrochemicals using combined fusion method and nonlinear modeling, journal of energy economics studies, (48), 194-1703.

Bani Mahdi., Bahman., Talebnia, Qodrat allh., Azvaji., Hussein., 2009, Investigating the relationship between environmental performance and financial performance, Journal of Financial Accounting and Auditing, (3) 1, 174149 .

Bae, H. S., 2017. The effect of environmental capabilities on environmental strategy and environmental performance of Korean exporters for Green Supply Chain Management. The Asian journal of shipping and logistics, 33(3), 167176.

Bai, Y., Hua, C., Jiao, J., Yang, M. and Li, F., 2018. Green efficiency and environmental subsidy: Evidence from thermal power firms in China. Journal of Cleaner Production, 188, pp.49-

Brown, H., \& Dray, J., 1996. Where the rubber meets the road: measuring the success of environmental programs. Journal of Environmental Quality Management, 5(3), 71-80. 
Chini frosh., Hamed. Sheikhzadeh., Hossein., 2010, The relationship between organizational performance and Green Supply Chain in Iran's petrochemicals (69).

Choi, Y., Bone, C. and Zhang, N., 2016. Sustainable policies and strategies in Asia: Challenges for green growth.

Dyer, J.H. and Singh, H., 1998. The relational view: Cooperative strategy and sources of inter organizational competitive advantage. Academy of management review, 23(4), pp.660-679.

Dean, T. J., \& Brown, R. L., 1995. Pollution regulation as a barrier to new firm entry: Initial evidence and implications for future research. Academy of Management Journal, 38(1), 288-303.

Gao, J., Xiao, Z., Cao, B., \& Chai, Q., 2018. Green supply chain planning considering consumer's transportation process. Transportation Research Part E: Logistics and Transportation Review, 109, 311-330.

Ghorban pour, Ahmad., Poya, alireza., Nazemi, Shamsedin., Azimi, Zahra., 2017. The Importance of green supply chain management measures in the Iranian oil field (FISM_FANP combined approach), journal of new research for decision making, (3) 2.

Ghorban pour, Ahmad., poya, alireza., Nazemi, Shamsedin., Azimi, Zahra., 2017. Designing a structural model for green supply chain management steps using the fuzzy interpretative structural modeling approach, Journal of operations research in its applications, (4) 51, 1-20.

Golicic, S.L. and Smith, C.D., 2013. A meta-analysis of environmentally sustainable supply chain management practices and firm performance. Journal of supply chain management, 49(2), pp.78-95.

Grant, R. M., 1999. The resource-based theory of competitive advantage: implications for strategy formulation. Journal of knowledge and strategy, 3-23.

Hart, S.L., 1995. A natural-resource-based view of the firm. Academy of management review, 20(4), pp.986-1014.

Hosseini, Asma., Irbandan, Javad., Mir jahan mard, Javad., 2014. Determination and prioritization of effective factors on the green supply chain using path analysis approach, journal of production management and operations, (2) $9,161-178$.

Imani, Din Muhammad., Ahmadi, afsaneh., 2009, Green Supply Chain Management, a new strategy for achieving competitive advantage, automobile engineering magazine and affiliated industries, (10) 1.

Judge, W. Q., \& Douglas, T. J., 1998. Performance implications of incorporating natural environmental issues into the strategic planning process: an empirical assessment. journal of management studies, 35(2), 241-262.

Kim, M.G., Woo, C., Rho, J.J. and Chung, Y., 2016. Environmental capabilities of suppliers for green supply chain management in construction projects: a case study in Korea. Journal of Sustainability, 8(1), p.82.

Khosravani, Farzaneh., 2015. Structuring the issue of developing a strategy for green supply of fossil fuels.

Lee, S. Y., 2008. Drivers for the participation of small and medium-sized suppliers in green supply chain initiatives. Supply Chain Management: An International Journal, 13(3), 185-198.

Lee, S. Y., 2015. The effects of green supply chain management on the supplier's performance through social capital accumulation. Supply Chain Management: An International Journal, 20(1), 42-55.

Liu, X. and Wen, Z., 2012. Best available techniques and pollution control: a case study on China's thermal power industry. Journal of Cleaner Production, 23(1), pp.113-121.

Menguc, B., Auh, S., \& Ozanne, L., 2010. The interactive effect of internal and external factors on a proactive environmental strategy and its influence on a firm's performance. Journal of business ethics, 94(2), 279-298.

Mian abadi, Abbas Ali., 2016. Supply Chain Management: definition, history, objectives, processes, benefits and barriers, Quarterly journal of market research applications. 
Nik nejad, Maryam., 2011. Green Supply Chain (with Case Study), Journal of supply chain management, (34).

Nasr Abadi, Zohre., 2014. Investigating the impact of audience's motivation on their attitudes about online Newspapers (Case Study of Qods Online). Faculty of management and accounting, Imam Reza international university.

Olfat, Laia., Khatami firooz abadi, Ali., Khoda Verdi, rohallah,, 2011. Requirements for realization of green supply chain management in Iran's automotive industry, Journal of management sciences of Iran, (21), 123-140.

Qazi Tabatabai, Mahmoud., Yousefi Afrashte, Majid., 2012. Providing a structure for assessing the environmentfriendly industries: applied to structural equation modeling, Quarterly journal of research and planning in higher education (64). 107-83.

Rostamzadeh, Reza., Mohammadi Siaban, Asqar Ali., 2016. Effects of environmental factors on green marketing performance; case study: Shirin Aal Co, magazine of valuation chain management, (1) 1.

Rojoei, Morteza., Ramezani, Maryam., Hesari, Mohammad Reza., Borborr jafari, Maryam., 2017. Designing performance evaluation indices using AHP and BSC methods in social security organization of Mashhad, (64) 17.

Raeisi, Razieh., 2016. Determining the efficiency and green productivity in Iran's thermal and non-thermal power plants by regarding the environmental perspectives and clean energy, P.H.D thesis, Tarbiat Modarres university, Faculty of management and economics.

Sarumpaet, S., 2006. The relationship between environmental performance and financial performance of Indonesian companies. Journal Akuntansi dan Keuangan, 7(2), pp-89.

Shah bandar zadeh, Hamid., Kabgani, Mohammad., 2017. Quantitative analysis of risks in green supply chain management using mathematical modeling, Quarterly journal of business research, (82), 1-32.

Sörbom, D., \& Jöreskog, K. G. (1981). The use of structural equation models in evaluation research. Univ., Depart. of Statistics.

Tavanir Specialist Company., 2016. Detailed statistics of Iran's power industry for strategic management in 2016.

Thurner, T.W. and Roud, V., 2016. Greening strategies in Russia's manufacturing-from compliance to opportunity. Journal of cleaner production, 112, pp.2851-2860.

Zhu, Q., Sarkis, J and Lai, K. H., 2008. Confirmation of a measurement model for green supply chain management practices implementation. International journal of production economics, 111(2), 261-273.

Zanjerehi, Mahmoud., Ardakani, Faezeh., Azizi, Fatima., moravaj, Somayeh., 2013. Presentation of the green assessment framework for manufacturing industries based on environmental performance and fuzzy approach (case study: tile, steel and textile industries of Yazd province) (1), 39-52. 